\author{
Dr. sc. Miodrag Mićović, redovni profesor \\ Pravni fakultet Univerziteta u Kragujevcu
}

\title{
DRUŠTVENO-GOSPODARSKA DIMENZIJA SPORTA
}

\author{
UDK: $330.35: 796$ \\ DOI: $10.31141 /$ zrpfs.2020.57.137.889 \\ Izvorni znanstveni rad \\ Primljeno: 25. IX. 2019.
}

Od Deklaracije o specifičnostima sporta i njegovoj društvenoj funkciji iz 2000. godine, pa preko Bele knjige o sportu iz 2007. godine i najnovijih dokumenata koji su doneti na nivou EU, u koje spadaju Zaključci o gospodarskoj dimenziji sporta i njegovim društveno-gospodarskim koristima ili Mišljenje Evropskog odbora regija o uključivanju sporta u program EU za razdoblje nakon 2020. godine, ističe se uloga i potreba jačanja društvene i gospodarske dimenzije sporta. U vezi sa tim ukazuje se da je sport: gospodarski pokretač rasta u smislu efekata koje ima na dodatnu vrednost, bruto domaći proizvod i kupovnu moć; međusektorski fenomen koji može bitno da utiče na stanje javnog zdravlja, regionalni razvoj i turizam; sektor u kome se pojavljuju brojne inovacije, u cilju postizanja boljih rezultata ili sprečavanja ozleda, pri čemu se one često prenose na druge sektore i tako putem roba ili usluga postaju dostupne drugim korisnicima, odnosno potrošačima (u ovom slučaju sportske inovacije služe kao platforma za pokretanje i razvoj novih proizvoda i usluga, odnosno kao činilac od značaja za izvoz i gospodarski rast). U radu su izloženi elementi društvene dimenzije sporta, kao i direktni i indirektni efekti sporta na gospodarski rast.

Ključne reči: sport, društvena, gospodarska, dimenzija, aktivnost, razvoj, rast.

\section{UVODNE NAPOMENE}

Povodom sporta uobičajeno se razmatraju pitanja koja se postavljaju u vezi sa različitim sportskim aktivnostima i delatnostima, koje prema Zakonu o sportu Republike Srbije ${ }^{1}$ predstavljaju konstitutivne elemente pojma sport. ${ }^{2}$ Dakle, analizira se sportska dimenzija onoga što se podvodi pod pojam sporta, pa se navodi da sportske aktivnosti, u najširem smislu reči, i takmičarske i rekreativne, na individualnom planu doprinose: ${ }^{3}$ razvoju i očuvanju fizičkih i intelektualnih

\section{Sl. glasnik RS, br. 10/16.}

2 Prema Zakonu o sportu, sport je deo fizičke kulture koji obuhvata svaki oblik organizovanog i neorganizovanog obavljanja sportskih aktivnosti i sportskih delatnosti od strane fizičkih i pravnih lica u sistemu sporta, u cilju zadovoljenja potreba čoveka za stvaralaštvom, afirmacijom, fizičkim vežbanjem i takmičenjem sa drugima (čl. 2. st. 2). Za razliku od ovakvog određenja sporta, Veće EU povodom određenja sporta akcenat stavlja na sportske aktivnosti (svi oblici telesne aktivnosti koji, kroz neobavezno ili organizovano učestvovanje, imaju za cilj izražavanje ili poboljšanje telesne spremnosti i mentalne dobrobiti, sklapanje društvenih veza ili postizanje rezultata na takmičenjima svih nivoa - videti: Bela knjiga o sportu, https://hrvatski-bocarski-savez. hr/cdn/ content/ 2016/ 10/Bijela-knjiga-o-sportu.pdf, str. 2).

3 O tome: Đurđević, N., Mićović, M., Vuković, Z., Ugovori u sportu, Kragujevac, 2014, str. 22. 
snaga čoveka; održavanju i unapređenju zdravstvenog stanja pojedinaca; razvoju samopouzdanja i poštovanja sopstvene ličnosti; toleranciji, kao preduslovu za život u demokratskom društvu; rehabilitaciji i integraciji osoba sa invaliditetom. ${ }^{4}$

Osim koristi koje se pomoću sporta mogu ostvariti na planu individualnog razvoja, sport ima važnu ulogu i za društveni rast i razvoj. S obzirom da su individualni i društveni razvoj uz pomoć sporta međusobno povezani, neophodno je da društvo prepozna značaj sporta za ukupni razvoj, te da u skladu sa određenim principima promoviše sportske aktivnosti. Tako je postupio francuski zakonodavac u Sportskom zakoniku, pa je na početku Zakonika istaknuta društvena dimenzija sporta putem sledećih opštih principa: ${ }^{5}$ fizičke i sportske aktivnosti predstavljaju važan element obrazovanja, kulture, integracije i društvenog života; one naročito doprinose borbi protiv školskog neuspeha i smanjenju socijalnih i kulturnih nejednakosti, kao i zdravlju; promocija i razvoj fizičkih aktivnosti i sporta za sve, posebno za osobe sa invaliditetom, je od opšteg interesa; jednak pristup muškaraca i žena sportskim aktivnostima, u svim njihovim oblicima, je od opšteg interesa; država, lokalne vlasti i njihove grupe, udruženja, sportski savezi, kompanije i njihove društvene institucije doprinose promociji i razvoju fizičkih i sportskih aktivnosti, uz osiguranje jednakog pristupa sportskim aktivnostima na celoj teritoriji (čl. L 100-1 i 100-2 Sportskog zakonika, modifikovan 12. maja 2019). Nešto od navedenog, ali ne u formi principa, sadržano je i u Zakonu o sportu Republike Srbije i Republike Hrvatske. ${ }^{6}$

Društvena dimenzija sporta prepoznata je u teoriji, pa se navodi da za svako društvo sport ima značaj ${ }^{7}$ jer: poboljšava kvalitet života u zajednici; obogaćuje društvene odnose i razvija fer plej; podstiče socijalnu koheziju i mobilizaciju ljudi, uzajamnu toleranciju i međukulturni dijalog; promoviše etičke vrednosti, ${ }^{8}$ uzajamno

4 Integracija obuhvata proces koji omogućava osobi sa invaliditetom da postane društveni akter. Integracija osoba sa invaliditetom podrazumeva da se oni nalaze u okruženju u kojem se osećaju dobro, gde pronalaze svoje mesto, gde su prihvaćeni od drugih kakvi jesu, sa svim različitostima. O tome: Giraudoux, J., Le sport est l'espéranto des races, http://sportcultureetsociete.e-monsite.com/pages/iiquel-role-joue-le-sport-dans-la-societe.html

5 U delu teoriji se ističe da je naslov „opšti principi“ „,nakinđuren“ i zavaravajućeg karaktera, kao i da odrednice gotovo da nemaju normativnu vrednost. Umesto navedenih ,principa“ bilo je bolje da je istaknut princip slobodnog pristupa fizičkim i sportskim aktivnostima, koji je definisao UNESCO 1978 godine tako što je rečeno da svi imaju fundamentalno pravo pristupa fizičkom obrazovanju i sportu, kao nezamenljivim činiocima za razvoj ličnosti. O tome: Buy, F. i dr., Droit du sport, Paris, 2009, str. 159, 527.

U Zakonu o sportu RS navedeno je da svi imaju pravo da se bave sportom pod jednakim uslovima (čl. 4), a u Zakonu RH (Narodne novine RH, br. 71/06, 150/08, 124/10, 124/11, 86/12, 94/13, 85/15, 19/16) osim što je promovisan prvo na bavljenje sportom pod jednakim uslovima (čl. 1. st. 3), određeno je da program sporta mora da sadrži program stvaranja uslova za bavljenje sportom u vaspitno-obrazovnom sistemu, kao i program stvaranja uslova za rekreativno bavljenje sportom radi zaštite i poboljšanja zdravlja građana RH (čl. 2. st. 3).

Đurđević, N., Mićović, M., Vuković, Z., nav. delo, str. 22

8 Radi se, pre svega, o sportskim etičkim vrednostima - da se pobedi u jednakim uslovima, uz poštovanje pravila igre. Međutim, iako se često govori o etičkim vrednostima, u teoriji je prisutan stav prema kome u današnjem sportu koji se temelji na novcu i procenama, koje sprovode međunarodne sportske organizacije, nema ni morala ni etike. O tome: Redeker, R., L'étique sportive est-elle le monastère des corps ou bien celui des âmes?, Zbornik radova: L'étique en matière sportive, Toulouse, 2014, str. 15. 
razumevanje i zbližavanje ljudi; ${ }^{9}$ umanjuje rizik od društvenih anomalija, kao što je uživanje droga, koje pogađaju sva moderna društva; doprinosi rastu zaposlenosti i smanjenju zdravstvenih troškova; doprinosi društvenom i ekonomskom rastu i razvoju.

Na osnovu navedenog može se reći da sport predstavlja važan društveni, ali i ekonomski fenomen, što je konstatovano u Beloj knjizi o sportu, uz napomenu da sport doprinosi stvaranju važnih vrednosti, kao što su kolektivni duh, solidarnost, tolerancija i poštena igra. ${ }^{10} \mathrm{~S}$ tim u vezi krajem 2018. godine Veće EU usvojilo je Zaključke o gospodarskoj dimenziji sporta i njegovim društveno-gospodarskim koristima. ${ }^{11} \mathrm{U}$ njima je istaknuto da je sport: gospodarski pokretač rasta u smislu efekata koje ima na dodatnu vrednost, bruto domaći proizvod i kupovnu moć; međusektorski fenomen koji može bitno da utiče na stanje javnog zdravlja, regionalni razvoj i turizam; sektor u kome se pojavljuju brojne inovacije, u cilju postizanja boljih rezultata ili sprečavanja ozleda, pri čemu se one često prenose na druge sektore i tako putem roba ili usluga postaju dostupne drugim korisnicima, odnosno potrošačima (u ovom slučaju sportske inovacije služe kao platforma za pokretanje i razvoj novih proizvoda i usluga, odnosno kao činilac od značaja za izvoz i gospodarski rast). ${ }^{12}$

U daljem radu biće izloženi elementi društvene dimenzije sporta, kao i direktni $\mathrm{i}$ indirektni efekti sporta na gospodarski rast.

\section{DRUŠTVENA DIMENZIJA SPORTA}

Na osnovama Kubertenove misli da je ,sport deo nasleđa svakog muškarca i svake žene i da ništa ne može nadoknaditi njegov nedostatak", kao i principa o slobodnom pristupu sportu koji je nezamenljiv činilac za razvoj ličnosti (definisao UNESCO 1978. godine), važnost sporta u evropskom društvu i njegovu specifičnu prirodu prepoznalo je Evropsko veće 2000. godine u svojoj Deklaraciji o specifičnostima sporta i njegovoj društvenoj funkciji u Evropi (Deklaracija iz Nice). U Deklaraciji se ističe da Zajednica mora, delujući prema raznim odredbama Ugovora, uzeti u obzir društvene, obrazovne i kulturne funkcije svojstvene sportu te ga činiti posebnim kako bi se etički kodeks i solidarnost, koja je važna za očuvanje njegove društvene uloge, poštovali i negovali. Društvena dimenzija sporta istaknuta je i u Beloj knjizi, koja je predstavljena od strane Evropske komisije 2007. godine, sa ciljem jačanja svesti o

9 Od drevnih Olimpijskih igara, sport je bio prilika za izgradnju odnosa među ljudima, za uvođenje primirja (i danas se primirje promoviše od strane Međunarodne fondacije za olimpijsko primirje) među narodima tokom igara. Sport je univerzalni jezik, način života, koji omogućava stvaranje mostova između socijalnih, religijskih i rodnih razlika, čime se pomaže očuvanju mira. O tome: Giraudoux, J., Le sport est l'espéranto des races, http://sportcultureetsociete.e-monsite.com/pages/ii-quel-role-joue-le-sport-dansla-societe.html

10 Bela knjiga o sportu, COM(2007)391, Brisel, 11.7.2007, https://hrvatski-bocarski-savez. hr/cdn/ content/ 2016/ 10/Bijela-knjiga-o-sportu.pdf

11 Sl. list EU, C 449 od 13. 12. 2018 (u daljem tekstu:Zaključci).

12 Videti tač. 9, 10, 17. Zaključaka. 
društvenoj ulozi sporta, ${ }^{13}$ kao i u Mišljenju Evropskog odbora regija o uključivanju sporta u program EU-a za razdoblje nakon $2020 .{ }^{14} \mathrm{U}$ navedenim dokumentima se naglašava da sport nije marginalna delatnost, nego prioritetno područje u pogledu ulaganja EU, sa značajnom ulogom u sferi zdravstva, obrazovanja, doprinosom na planu održivog razvoja, angažovanja i integracije građanstva, sa potencijalima da približi ljude jedne drugima i bude brana protiv rasizma, nasilja i korišćenja nedozvoljenih sredstava u funkciji postizanja rezultata. ${ }^{15}$

Kada se radi o zdravlju, sportske (telesne) aktivnosti se pojavljuju kao ključni činilac za postizanje boljeg zdravlja i usvajanje zdravih životnih navika. Nedostatak takvih aktivnosti uzrokuje, u velikom broju slučajeva, povećanje telesne težine (jednom povećana telesna masa u principu ostaje pratilac čovekov tokom čitavog života) i niz hroničnih bolesti (kardiovaskularna oboljenja, dijabetes, mentalne bolesti) koje smanjuju kvalitet života, ugrožavaju živote pojedinaca, što dalje ima za posledicu rast tereta za zdravstveno osiguranje i ekonomiju. Uloga sporta, kao preventivnog činioca, za ostvarenje kvalitetnog zdravlja je nezamenljiva i značajnija od uticaja koji bi, u tom pogledu, mogao imati neki drugi društveni pokret. Kako bi se ostvarila zdravstveno-preventivna uloga sporta Svetska zdravstvena organizacija je preporučila da je potrebno preduzeti mere kako bi se zadovoljili neophodni standardi od najmanje 30 minuta umerene telesne aktivnosti dnevno za odrasle i 60 minuta za decu. ${ }^{16}$

U pogledu obrazovanja, postoji neraskidiva veza i uticaj sporta na obrazovanje. Svojom ulogom u formalnom i neformalnom obrazovanju sport jača ljudski kapital. Naime, vrednosti koje se sportom prenose pomažu u razvoju znanja, motivacije, veština i spremnosti za lični napor. Kako sportske aktivnosti potpomažu kvalitetno odvijanje obrazovnog procesa to se na nivou EU daju podsticaji ${ }^{17}$ za intenziviranje telesnih aktivnosti u školama, kako bi se postigla ravnoteža sa novousvojenim navikama dece da sve obavljaju u sedećem položaju. U tom cilju predviđeno je

13 Bela knjiga o sportu, https://hrvatski-bocarski-savez.hr/cdn/content/2016/10/Bijela-knjiga-osportu.pdf, str. 2.

14 Sl. list EU, C 461 od 21. 12. 2018.

15 Nasuprot segmentima društvene dimenzije sporta koji su navedeni u dokumentima EU sociološka shvatanja u pravi plan stavljaju društvene funkcije sporta koje primarno služe dobrobiti čoveka i to: socio-emocionalnu funkciju (doprinosi očuvanju društvene i psihološke stabilnosti lica koja učestvuju u sportskim aktivnostima); funkciju socijalizacije (ostvaruje se kroz podsticanje i ugledanje); integrativnu funkciju (počiva na izreci prema kojoj sport vezuje ljude, doprinosi harmonizaciji odnosa između ljudi i različitih društvenih grupa); političku funkciju (sport ima moć da upravlja i i usmerava narodne mase, zbog čega se često stavlja u službu nacionalne politike); funkciju društvene mobilnosti, odnosno pokretljivosti (razlikuje se horizontalna pokretljivost, pod kojom se podrazumeva kretanje sportista između različitih društava i kultura uz prevazilaženje jezičkih, verskih, rasnih i drugih barijera posredstvom sportskih aktivnosti i vertikalna funkcija pokretljivosti, pod kojom se podrazumeva promena, odnosno poboljšanje društvenog statusa sportiste). O tome: Vuković, Z., Društvena vrednost sporta, Zbornik radova: XXI vek - vek usluga i Uslužnog prava, knjiga 9, Kragujevac, 2018, str. 167.

${ }_{16}$ Bela knjiga o sportu, https://hrvatski-bocarski-savez.hr/cdn/content/2016/10/Bijela-knjiga-osportu.pdf, str. 4.

17 O tome: Evropska dimenzija sporta, https://eur-lex.europa.eu/legal-content/ HR/TXT/? uri= LEGISSUM \%3Aef0025; EU Guidelines on Dual Careers of Athletes, http://ec.europa. eu/assets/ eac/ sport/library/documents/dual-career-guidelines-final_en.pdf, str. 17; Bela knjiga o sportu, https://hrvatskibocarski-savez.hr/cdn/content/2016/10/Bijela-knjiga-o-sportu.pdf, str. 6. 
uvođenje nagrade Evropski znak za škole koje su aktivno uključene u proces potpore telesnim aktivnostima. Takođe, date su smernice o dvojnim karijerama za sportiste kako bi se osiguralo pružanje kvalitetnog obrazovanja uz sportske treninge. ${ }^{18}$

Doprinos sporta održivom razvoju, koji zadovoljava potrebe današnjice bez ugrožavanja mogućnosti budućih generacija da zadovolje svoje potrebe, ostvaruje se tako što se sportske organizacije i organizatori sportskih događaja podstiču da sprovode ekološki održive aktivnosti, što znači bez ugrožavanja životne sredine. Podsticaji se ogledaju u davanju određenih povlastica. ${ }^{9}$

Kada se radi o ulozi sporta u pogledu angažovanja građanstva, nesporno je da sport predstavlja najveći građanski pokret, a volonterske aktivnosti (volontiranje može biti formalno i neformalno, a podrazumeva slobodnu odluku, izbor i motivaciju, bez razmišljanja o financijskoj nadoknadi) u sportu najpopularniji oblik socijalnog angažovanja u Evropi. Građanima se na taj način pruža prilika za neformalno obrazovanje i sticanje novih veština, čime se popravlja njihova zaposlenost, jača osećaj pripadnosti društvu i smanjuje rizik od asocijalnog, odnosno delikventnog ponašanja. ${ }^{20}$

Prema Mišljenju Evropskog odbora regija o uključivanju sporta u program EU, sport predstavlja značajan alat za socijalizaciju, instrument za lakše ostvarivanje jednakosti i integracije. ${ }^{21}$ Pri tome se misli, pre svega, na mogućnost da se uz pomoć sporta ostvari lakše integracija migranata i stranaca u društvo, kao i osoba sa invaliditetom. U tom cilju podstiču se sportske organizacije da infrastrukturu prilagode potrebama osoba sa posebnim potrebama kako bi mogle da im pristupe.

Osim socijalne uloge na unutrašnjem planu, sport ima takvu ulogu i na spoljnjem planu, kada se govori o deljenju sopstvenih vrednosti sa drugim delovima sveta. Sport se koristi povodom raznih aspekata spoljnih odnosa: kao element programa pomoći, kao element dijaloga sa zemljama partnerima, kao deo javne diplomatije, kao sredstvo dijaloga među kulturama. ${ }^{22} \mathrm{Na}$ kraju, sport, preko sportskih organizacija,

18 U skladu sa datim smernicama u Francuskoj je propisano sledeće: đaci i studenti imaju pravo na specijalni režim obrazovanja kako bi mogli nesmetano da se bave sportskim aktivnostima (čl. 2219 i 221-10. Zakona o sportu Francuske). Kada se radi o fakultetima, studenti imaju pravo da studiraju u skladu sa programima prilagođenim njihovim potrebama, da se obrazuju na daljinu i koriste audiovizuelna sredstava telekomunikacije (čl. 611-4. Zakona o obrazovanju Francuske); da im bude pružena podrška na planu režima studija (uslovi za odsustvo sa predavanja i praktične nastave, pomeranje datuma polaganja ispita), na sportskom (korišćenje univerzitetskih sportskih objekata van uobičajenih termina, prisustvo trenera, besplatna studentska karta), na socijalnom planu (redukcija cene studiranja, prioritet $\mathrm{u}$ pogledu smeštaja, mogućnost smeštaja tokom letnjih meseci, smanjenje zakupnine). O tome: Université libre de Bruxelles Statut du sportif de haut niveau, http://www.iclub.be/ doc/107/ Statut \%20 Sportif\%20 de\%20haut\% 20niveau\% 202016\% 202017. pdf.

19 Bela knjiga o sportu, https://hrvatski-bocarski-savez.hr/cdn/content/2016/10/Bijela-knjiga-o-sportu. pdf, str. 11.

20 Financiranje sporta u Republici Hrvatskoj s usporednim prikazom financiranja u europskoj uniji, https:// sdus.gov.hr/UserDocsImages/Arhiva/Media/1114/financiranje_sporta_u_rh_s_usporednim_prikazom_u_eu. pdf, str. 43.

21 Tač. 18. Mišljenja Evropskog odbora regija - Uključivanje sporta u program EU-a za razdoblje nakon 2020.

22 Bela knjiga o sportu, https://hrvatski-bocarski-savez.hr/cdn/content/2016/10/Bijela-knjiga-o-sportu. pdf, str. 10 . 
ima i zaštitnu funkciju koja se ostvaruje na planu mira, kroz preduzimanje mera radi sprečavanja rasizma i nasilja, ${ }^{23}$ i zaštite zdravlja, kroz primenu mera u cilju sprečavanja dopinga. Kada se radi o borbi protiv nasilja, koje je sve prisutnije na sportskim događajima, pri čemu se često nastavlja u gradskoj sredini, sportske organizacije deluju na različite načine kako bi se rasistički i ksenofobični ispadi sprečili: izriču se oštre kazne organizatorima sportskih događaja, razmenjuju se informacije o rizičnim navijačima između policijskih službi i/ili sportskih tela, promoviše se multidisciplinarni pristup sprečavanju antisocijalnog ponašanja s posebnim naglaskom na društveno-obrazovnim aktivnostima kao što je fan coaching (dugoročni rad s navijačima kako bi oni razvili pozitivan i nenasilan stav) ${ }^{24}$ Sto se tiče dopinga, jasno je da on predstavlja pretnju sportu u celome svetu, jer ruši načelo otvorenog i poštenog takmičenja, narušava imidž sporta i predstavlja ozbiljnu pretnju zdravlju pojedinaca. Zato je u planu rada EU u području sporta (period 1. juli 2017. - 31. decembar 2020) određeno da je borba protiv dopinga ključna tema kojom će se baviti u funkciji obezbeđenja integriteta sporta. ${ }^{25} \mathrm{U}$ tom cilju preduzimaju se mere u pravcu razvoja mreže nacionalnih organizacija za suzbijanje dopinga, podstiče partnerstvo između agencija za sprovođenje zakona država članica (granična policija, nacionalna i lokalna policija, carina), laboratorija $\mathrm{s}$ akreditacijom Svetske agencije za borbu protiv dopinga i INTERPOL-a kako bi se na vreme i u sigurnoj okolini razmenile informacije o novim supstancama koje se koriste u svrhu dopinga i o novim načinima dopinga. ${ }^{26}$ Inače, iako se danas govori o borbi protiv dopinga u funkciji obezbeđenja integriteta sporta, istina je da je ta borba započeta sa ciljem da se zaštiti zdravlje sportista. Naime, Olimpijski komitet je inicirao pitanje borbe protiv dopinga nakon smrti bicikliste Knud Enemark Jensen, tokom Olimpijskih igara u Rimu, koji je koristio amfetamin. Ova dimenzija borbe ostaje i dalje, s tim što se u prvi plan stavlja integritet sporta i zaštita sportske etike, pa se ističe da kada sportisti koriste nedozvoljene supstance radi poboljšanja svojih

23 Evropski institucionalni odgovor na problem nasilja bio je definisan u Konvenciji o nasilju i nedoličnom ponašanju gledalaca na sportskim priredbama, posebno na fudbalskim utakmicama (usvojena 19. 8. 1985. godine), koja je doneta kao reakcija na tragični događaj koji se odigrao na Hejselu (29. 5. 1985. godine odigrana utakmica Kupa šampiona između Liverpula i Juventusa, na kojoj je bilo 39 mrtvih). Navedena Konvencija je 1. 11. 2017. godine zamenjena Konvencijom o integrisanom pristupu bezbednosti, sigurnosti i uslugama na fudbalskim utakmicama i drugim sportskim događajima. Ovom Konvencijom se nastoji da se osigura da se fudbalski i drugi sportski događaji odvijaju u sigurnom, bezbednom i ugodnom okruženju za sve pojedince kroz implementaciju integrisanog pristupa sigurnosti, bezbednosti i usluga na sportskim priredbama od strane mnoštva aktera koji rade partnerski, vođeni etosom saradnje. Konvencijom je predviđeno više mera za sprečavanje i kažnjavanje dela nasilja i nedoličnog ponašanja, uključujući zabranu stadiona, procedure sankcija u zemlji u kojoj je počinjeno krivično delo ili u državi prebivališta ili državljanstva, ili ograničenja putovanja u inostranstvo na fudbalske događaje. $\mathrm{O}$ tome: Đurđević, N., Konvencija o integrisanom pristupu bezbednosti, sigurnosti i uslugama na fudbalskim utakmicama i drugim sportskim događajima, Zbornik radova: XXI vek - vek usluga i Uslužnog prava, knjiga 9, Kragujevac, 2018, str. $144-147$.

24 Isto, str. 8.

25 Rezolucija Veća i predstavnika vlada država članica o planu rada Europske unije u području sporta (tač. 12), Sl. list EU, C 189 od 15. 6. 2017.

26 Bela knjiga o sportu, https://hrvatski-bocarski-savez.hr/cdn/content/2016/10/Bijela-knjiga-osportu.pdf, str. 5 . 
mogućnosti, oni negiraju sportski duh da se pobedi pod jednakim uslovima i uz poštovanje sportskih pravila. ${ }^{27}$

\section{GOSPODARSKA DIMENZIJA SPORTA}

U planovima rada EU-a u području sporta $(2011$ - 2014, 2014 - 2017. i 2017 2020), ističe se važnost gospodarske dimenzije sporta kao pokretača rasta (u smislu uticaja koji ima na dodatnu vrednost, bruto domaći proizvod i kupovnu moć), zaposlenosti, inovacija, čime sportski sektor daje direktan doprinos gospodarstvu. ${ }^{28}$ Kada se radi o inovacijama, njih podstiče izražena sportska konkurencija. Mnogi sportovi privlače značajne finansijske resurse zahvaljujući kojima se vrše velika ulaganja u razvoj inovativne opreme, koja učesnicima ili timovima omogućava da ostvare konkurentsku prednost. Inovacije su dovele do toga da sportska tehnologija predvodi u određenim područjima primenjene nauke, kao što su tekstilna tehnologija, mehanika, novi materijali, senzori, dizajn. ${ }^{29}$

Osim direktnog doprinosa, sportski sektor i indirektno daje značajan doprinos gospodarstvu, s tim što on nije propraćen i vrednovan na adekvatan način. Sport je međusektorski fenomen, čijim se delovanjem obezbeđuje razvoj, povećavaju prihodi (posmatrano u odnosu na prihode koji se neposredno ostvaruju u sportskoj industriji) ili smanjuju rashodi u pojedinim oblastima društvenog života (na primer, volonterski rad, ${ }^{30}$ koji je u značajnoj meri prisutan u sportu, omogućava da se ostvare velike materijalne uštede zbog toga što se obavlja dobročino). On ima naročit gospodarski značaj u pogledu smanjenja troškova neophodnih za održanje zdravlja na zadovoljavajućem nivou (uz pomoć sporta mogu da se ostvare značajne uštede vezano za lečenje bolesti koje su povezane sa telesnom neaktivnošću, i obrnuto, da se povećaju troškovi ako stanovništvo ne upražnjava sportske aktivnosti), za lokalni, regionalni, ruralni razvoj i regeneraciju gradova, za turizam. ${ }^{31}$

27 Chaussard, C., L'etique sportive, fondement de la lutte contre le dopage, Zbornik radova: L'étique en matière sportive, Toulouse, 2014, str. 54.

28 Tač. 1, 2, 6. Zaključaka.

29 Zaključci Veća i predstavnika vlada država članica, koji su se sastali u okviru Veća, o sportu kao pokretaču inovacija i gospodarskog rasta (tač. 4 - 6), Sl. list EU, C 436 od 5. 12. 2014.

30 U Danskoj, 360.000 osoba rade kao volonteri, prosečno 3,4 sata nedeljno, što odgovara doprinosu u vrednosti od 841 milion evra, što čini 62\% finansijskih prihoda koje ostvaruje sportski sektor; u Švedskoj, 600.000 volontera radi između 3,9 - 6,8 sati nedeljno, što odgovara doprinosu u vrednosti od 1.214 miliona evra, a čini 45\% finansijskih prihoda koje ostvaruje sportski sektor; u Češkoj, 270.000 volontera prosečno 5 sati nedeljno, što odgovara doprinosu u vrednosti od 193,5 miliona evra, a čini 36,8\% finansijskih prihoda koje ostvaruje sportski sektor; u Austriji, 496.815 volontera prosečno 3 sati nedeljno, što odgovara doprinosu u vrednosti od 682 miliona evra, a čini 16,4\% finansijskih prihoda koje ostvaruje sportski sektor. O tome: Financiranje sporta u Republici Hrvatskoj s usporednim prikazom financiranja u europskoj uniji, https://sdus. gov.hr/UserDocsImages/ Arhiva/Media/1114/financiranje_ sporta_u_rh_s_usporednim_prikazom_u_eu.pdf, str. 155 - 166.

31 O ovome videti: tač. 10, 14, 15, 16, 18, 28. Zaključaka; Bela knjiga o sportu, https://hrvatskibocarski-savez.hr/cdn/ content/ 2016/10/Bijela-knjiga-o-sportu.pdf, str. 11. 
Prema najnovijim procenama udeo sporta u nacionalnim gospodarstvima je uporediv s udelom poljoprivrede, šumarstva i ribarstva zajedno. Sportska industrija predstavlja $2 \%$ ukupnog bruto domaćeg proizvoda EU i osigurava 7,3 miliona radnih mesta u Evropi, odnosno 3,5 \% ukupne zaposlenosti u EU. Kad je reč o sektoru turizma, godišnje se ostvari između 12 i 15 miliona međunarodnih putovanja $\mathrm{u}$ cilju učestvovanja u sportskim događanjima ili aktivnostima. ${ }^{32}$ Po procenama onih koji se bave turističkim prometom i prihodima od turizma, unutar prihoda nalazi se minimalno pet posto prihoda direktno vezanih uz sport. ${ }^{33} \mathrm{U}$ Republici Hrvatskoj udeo sporta u BDP-u je 676 miliona evra (1,54\%), s tim što je 27.908 ljudi je zaposleno u sportskom sektoru $(1,83 \%) \cdot{ }^{34}$ Ako se posmatra prihod hrvatskog turizma može se izračunati da je zahvaljujući sportu turistička privreda ostvarila prihod od 400 do 500 miliona evra. ${ }^{35}$

Radi merenja gospodarskih doprinosa sporta nacionalnoj ekonomiji u Beloj knjizi je istaknuta potreba da se razvije statistička metoda za merenje koja bi poslužila kao osnov za stvaranje evropskog satelitskog računa za sport, ${ }^{36}$ kao pratećeg računa kojim se proširuje analitički kapacitet sistema nacionalnih računa. Do danas sveukupno devet država (Austrija, Belgija, Kipar, Litvanija, Holandija, Nemačka, Poljska, Portugalija i Velika Britanija) članica EU održava celovite nacionalne satelitske račune za sport, a dodatnih pet zemalja (Bugarska, Francuska, Luksemburg, Slovačka i Španija) beleži skup podataka povezanih sa sportom kojima se omogućuje viši stepen preciznosti rezultata. ${ }^{37}$

\section{ZAKLJUČAK}

Osim sportske dimenzije, koja se ostvaruje između učesnika, direktnih i indirektnih, sportskih aktivnosti, a od značaja je za individualni razvoj i postignuća, sport, kao međusektorski fenomen, ima i društvenu i gospodarsku dimenziju ili funkciju. Društvena i gospodarska dimenzija sporta su retko predmet analize, iako, sa stanovišta opštih interesa, imaju možda i veći značaj u odnosu na sportsku dimenziju, koja omogućava individualni razvoj i zadovoljenje. Razume se, između njih postoji tesna veza, jer izražena brojnost onih koji se bave sportskim

32 Mišljenje Evropskog odbora regija - Uključivanje sporta u program EU za razdoblje nakon 2020 (tač. 2), Sl. list EU, C 461 od 21. 12. 2018.

33 U Republici Srbiji, prema podacima iz 2011. godine, usluge sporta nalazile su se na trećem mestu po turističkoj potrošnji i iznosile su 19.86 milijardi dinara ili 14,3\% u ukupnoj potrošnji turista u Srbiji. O tome: Vukasović, S., Satelitski račun u turizmu i njegova primena u Srbiji, http:// nardus. mpn. gov. rs/ bitstream/ handle/ 123456789/1206/Disertacija.pdf?sequence=1\&isAllowed=y, str. 142.

34 Gospodarska dimenzija sporta u fokusu Europske komisije, https://www.hoo.hr/hr/olimpizam/ medunarodna-suradnja/5204-gospodarska-dimenzija-sporta-u-fokusu-europske-komisije

35 Mateša podržava Miškovića, http://www.novilist.hr/Sport/Nogomet/MATESA-PODRZAVAMISKOVICA-Neka-drzava-vrati-sportu-veci-dio-onoga-sto-sport-doprinosi-drzavi?meta_refresh=true

36 Bela knjiga o sportu, https://hrvatski-bocarski-savez.hr/cdn/ content/ 2016/10/Bijela-knjiga-o-sportu. pdf, str. 12 .

37 Tač. 12. Zaključaka. 
aktivnostima i dobri rezultati, ostvareni u skladu sa sportskim pravilima, doprinose i da rezultati na društvenom i gospodarskom planu budu bolji. Važnost sporta i njegova specifična priroda potvrđena je od strane evropskog društva donošenjem 2000. godine Deklaracije o specifičnostima sporta i njegovoj društvenoj funkciji (tzv. Deklaracija iz Nice).

Ako je društvena dimenzija sporta po pitanju zdravlja, obrazovanja ili socijalizacije i integracije više-manje jasna i ne dovodi se u pitanje, čini se da nije tako kada se govori o gospodarskoj dimenziji sporta. Često se postavljaju pitanja o ulaganjima u sport, pri čemu se zanemaruje ili ne sagledava činjenica da sport u načelu više doprinosi bruto domaćem proizvodu nego što dobija, kao i da je udeo sporta u nacionalnoj ekonomiji mnogo veći od onoga koji imaju druge delatnosti. Razlog tome treba tražiti pre svega u tome što se zanemaruje značaj sportskih inovacija ili rad volontera za porast zaposlenosti i razvoj gospodarstva u celini.

\section{SOCIAL AND ECONOMIC DIMENSION OF SPORT}

The role of sport and the need to strengthen the social and economic dimension of sport has been emphasized in numerous documents adopted at the EU level, starting with the Declaration on the specific characteristics of sport and its social function in Europe which was adopted in 2000, through the White Paper on Sport (2007/2261(INI)) and the latest EU documents including Conclusions on the economic dimensions of sport and its socio-economic benefits or Opinion of the European Committee of the Regions - Mainstreaming sport into the EU agenda post-2020. In this regard, it is pointed out that sport represents: an economic driver of growth in terms of the effects it has on the added value; gross domestic product and purchasing power; cross-sectoral phenomenon that can significantly affect the state of public health, regional development and tourism; a sector in which numerous innovations appear in order to achieve better results or to prevent injuries, whereby they are often transferred to other sectors and thus become available to other users or consumers through goods or services (in this case, sports innovations serve as a platform for launching and the development of new products and services, or as a factor of importance for exports and economic growth). The paper presents elements of the social dimension of sport, as well as the direct and indirect effects of sports on economic growth.

Key words: sport, social, economic, dimension, activity, development, growth. 